\title{
Removal of Heavy Metal Ions from Industrial Wastewater by Scolecite
}

\author{
Almalih MA ${ }^{1 *}$, Salih A ${ }^{1}$, Dafaallah AA ${ }^{2}$, Magid SAA ${ }^{3}$, Gizouli AME${ }^{1}$ and Tilal AS ${ }^{1}$
}

${ }^{1}$ Department of Chemistry, Faculty of Science and Technology, Omdurman Islamic University, Sudan

${ }^{2}$ Department of Chemistry, Faculty of Science, Sudan University of Science and Technology, Sudan

${ }^{3}$ Department of Chemistry, Faculty of Science and Technology, Elnelain University, Sudan

\begin{abstract}
It is a strategic target now to reuse treated industrial waste water for washing, irrigation etc., to efficiently manage and maximize Sudanese's water resources. The aim of the present work was to study the performance of natural zeolite (scolecite) for removing heavy metals from industrial waste water. Natural zeolite deposit sample was collected from Bayooda desert. Natural zeolite used (scolecite) was characterized by XRD, XRF, SEM and FTIR instruments. The physical properties ( $\mathrm{pH}, \mathrm{EC}$, TDS, COD, BOD, total hardness) and chemical properties $\left(\mathrm{Ni}^{2+}, \mathrm{Pb}^{2+}, \mathrm{Zn}^{2+}, \mathrm{Cd}^{2+}, \mathrm{Fe}^{+}, \mathrm{Cr}^{3+}\right)$ of the collected industrial waste water samples were investigated. Zeolite sorbed around 95.8, 88.1, 48, 50, 19.7 and $99.9 \%$ of $\mathrm{Ni}^{2+}, \mathrm{Pb}^{2+}, \mathrm{Zn}^{2+}, \mathrm{Cd}^{2+}, \mathrm{Fe}^{3+}$ and $\mathrm{Cr}^{3+}$ metal concentrations respectively. According to the percentage sorption values, the selectivity sequence of studied metals by natural zeolite can be given as $\mathrm{Cr}^{3+}>\mathrm{Ni}^{2+}<\mathrm{Pb}^{2+}<\mathrm{Cd}^{2+}<\mathrm{Zn}^{2+}>\mathrm{Fe}^{3+}$. These results show that natural zeolites hold great potential to remove cationic heavy metal species from industrial wastewater.
\end{abstract}

Keywords: Scolecite; Industrial wastewater; Heavy metal ions

\section{Introduction}

Scolecite is a tectosilicate mineral belonging to the zeolite group; it is a hydrated calcium silicate, $\mathrm{CaAl}_{2} \mathrm{Si}_{3} \mathrm{O}_{10} \cdot 3 \mathrm{H}_{2} \mathrm{O}$. Only minor amounts of sodium and traces of potassium substitute for calcium. There is an absence of barium, strontium, iron and magnesium [1,2]. Scolecite is isostructural (having the same structure) with the sodium-calcium zeolite mesolite and the sodium zeolite natrolite, but it does not form a continuous chemical series with either of them [1]. It was described in 1813, and named from the Greek word, $\sigma \kappa \omega \dot{ } \lambda \eta \xi=$ 'worm' because of its reaction to the blowpipe flame. Scolecite is a common zeolite. It is a mineral of secondary origin, and occurs with other zeolites in the amygdaloidal cavities (cavities filled with secondary minerals) of weathered basalts, also in gneisses and amphibolites, and in laccoliths and dikes derived from syenitic and gabbroic magmas, and in contact metamorphic zones. It is a hydrothermal mineral derived from low temperature alteration of basalts and related rocks, associated with other zeolites, calcite, quartz and prehnite. It can be found on top of the calcium zeolites heulandites, stilbite and epistilbite [2]. Associated minerals include quartz, apophyllite, babingtonite, heulandite, stilbite and other zeolites. Due to their structural characteristics, natural zeolites can be used in several applications, from which Pansini [3] reviewed those of environmental interest. For example Zamzow et al. [4] used clinoptilolite to remove $\mathrm{Al}, \mathrm{Fe}, \mathrm{Cu}$, and $\mathrm{Zn}$ from copper mine wastewater to below drinking water standards. Ouki and Kavannagh [5] showed that clinoptilolite and chabazite differ in their performance regarding capacity and selectivity. Other authors have demonstrated natural zeolites exhibit excellent selectivity a number of hazardous cations, a very moderate environmental impact [6-8]. The characteristics of industrial wastewater vary widely from industry to industry, and even within the same industry, depending on the raw materials used, processes employed, and various other factors [9]. Natural zeolites are especially attractive for removing heavy metal ions from effluent wastewaters mainly of industrial origin [5]. Zeolite media is a versatile product; it works the same way as any cation exchanger. $\mathrm{Ca}^{2+}, \mathrm{Mg}^{2+}$ and heavy metals ions are replaced on one to one basis with sodium or potassium through the ion exchange process [11]. Our objective in this study is to investigate the removal of inorganic pollutants like $\mathrm{Ni}^{2+}, \mathrm{Pb}^{2+}, \mathrm{Zn}^{2+}, \mathrm{Cd}^{2+}, \mathrm{Fe}^{3+}$ and $\mathrm{Cr}^{3+}$ metal ions from a model solution by the scolecite natural zeolite (SNZ).

\section{Materials and Methods}

The sample of natural zeolite scolecite collected from Bayouda desert. It locates west of Kadabas, and south of Nubian Desert. The Bayouda volcanic field located:

Latitude: $18.330^{\circ} 18.20^{\prime} 0^{\prime \prime} \mathrm{N}$

Longitude: $32.75^{\circ} 32.45^{\prime} 0^{\prime \prime} \mathrm{E}$

There are four industrial wastewaters from:

1. Tannery in Khartoum.

2. Paints factory in Khartoum industrial area.

3. Petroleum water from Foloug field in Southern Sudan.

4. Mahmoud Sharif's electricity station. Samples collected and stored in one liter plastic container, and kept in refrigerator.

\section{Chemicals}

$\mathrm{HCl}(0.1 \mathrm{M}), \mathrm{NaCl}(1 \mathrm{M})$, sulfuric acid reagent $(453.5 \mathrm{~mL}$ conc. $\mathrm{H}_{2} \mathrm{SO}_{4}+5.5 \mathrm{~g} \quad \mathrm{Ag}_{2} \mathrm{SO}_{4}$ ), standard potassium dichromate (4.913 g $\mathrm{K}_{2} \mathrm{Cr}_{2} \mathrm{O}_{7}$ in $167 \mathrm{~mL} \mathrm{H}^{2} \mathrm{SO}_{4}+33.3 \mathrm{~g} \mathrm{HgSO}_{4}$ and dilute to 1 Liter), standard ferrous ammonium sulfate $(0.1 \mathrm{M})$, ferrion indicator. Phosphate buffer, magnesium sulfate, calcium chloride, ferric chloride and manganese(II) sulfate solution. EDTA (4 g disodium salt in $500 \mathrm{~mL}$ distilled water and dilute to (1 Liter). Total hardness buffer solution. Total hardness indicator tablets.

\section{Instruments}

1. X-Ray diffract meter (XRD), system: Philips, Model: X-pert

*Corresponding author: Almalih MA, Department of Chemistry, Faculty of Science and Technology, Omdurman Islamic University, Sudan, Tel: 249 (187) 511 525; Email: zubairmaleeh@yahoo.com

Received April 01, 2015; Accepted June 13, 2015; Published June 18, 2015

Citation: Almalin MA, Salih A, Dafaallah AA, Magid SAA, Gizouli AME, et al. (2015) Removal of Heavy Metal lons from Industrial Wastewater by Scolecite. J Environ Anal Toxicol 5: 302. doi:10.4172/2161-0525.1000302

Copyright: (c) 2015 Almalih MA, et al. This is an open-access article distributed under the terms of the Creative Commons Attribution License, which permits unrestricted use, distribution, and reproduction in any medium, provided the original author and source are credited. 
PRO stress $\mathrm{XRD}$ analyzer $\mathrm{Cu}$-target radiation.

2. Atomic Absorption spectrophotometer (A.A.S); Perkin Elmer Model; 2380, flame double beam systems.

3. X-Ray Fluorescence (XRF) Model: ARL 9900 Series, Intelli power X-ray analyzer. Thermo Scientific, Belgium.

4. Infra-Red (IR) Spectrophotometer: Model: FTIR -8400S, Fourier Transform Infrared Spectrophotometer, Shimadzu.

5. Scanning Electron Microscope: Model: TESCAN. Oxford Instrument Company, using energy dispersive spectrometry (EDS) system.

6. Conductivity Meter: Model 4320 Jenway.

7. $\mathrm{pH}$ Meter: Model Corning Pinnacle $555 \mathrm{pH}$ ion meter.

8. COD Reactor.

\section{Method}

A sample of (scolecite natural zeolite) $2 \mathrm{~g}$ as Na- Zeolite (315$500 \mu \mathrm{m})$ grain-size was placed in a beaker. Before determined concentrations of heavy metal ions from industrial wastewater samples, adjusted to decrease $(\mathrm{pH})$ with Nitric acid. Then was added $50 \mathrm{~mL}$ industrial wastewater which had six heavy metal ions $\left(\mathrm{Ni}^{2+}, \mathrm{Pb}^{2+}, \mathrm{Zn}^{2+}\right.$, $\mathrm{Cd}^{2+}, \mathrm{Fe}^{3+}$, and $\left.\mathrm{Cr}^{3+}\right)$ To facilitate extraction of the heavy metal ions. Stirring: vigorous shaking was applied for $10 \mathrm{~min}$ as contact time. The solution was then filtered at room temperature $25^{\circ} \mathrm{C}$, and the filtrate was analyzed by (A.A.S) to determine the residual of the heavy metal ions concentration.

\section{Results and Discussion}

Results of scolecite were shown in Tables 1 and 2, the chemical composition of the natural zeolite as oxides. $\mathrm{SiO}_{2}$ and $\mathrm{AL}_{2} \mathrm{O}_{3}$ percentage were found high in sample. This indicates that silicate and aluminate are important components in natural zeolites. Percentages of metal oxides $\left(\mathrm{Fe}_{2} \mathrm{O}_{3}^{+}, \mathrm{CaO}^{+}, \mathrm{MgO}^{+}, \mathrm{Na}_{2} \mathrm{O}^{+}, \mathrm{K}_{2} \mathrm{O}\right)$ were found $(32.31 \%)$ and this indicates that all cations were exchanged by $\mathrm{Na}^{+}$ions to form sodium zeolite as cation exchanger. The exchange of multivalent metal ions can be achieved in low $\mathrm{pH}$ to ensure the solubility of heavy metal cations according to Blanchard [11]. Characteristics of Scolecite were drown in Figures 1-3. The identification of the zeolite was carried by X-Ray diffract meter (XRD), system: Philips, Model: X-pert PRO stress $\mathrm{XRD}$ analyzer $\mathrm{Cu}$-target radiation, used in the present work phase analysis was achieved by using XRD, sample was analyzed and found to be scolecite Figure 1. SEM photograph of zeolite particles is shown in Figure 2. It is clear that particles are rectangular in shape with sharp edges. In the infrared spectrum shown in Figure 3 of Scolecite without chemical processing but grinding as powder. It is reported the following positions of these bands: $462.88 \mathrm{~cm}^{-1}$ bending $\left[\mathrm{O}-\mathrm{Si}(\mathrm{Al}) \mathrm{O}^{+} \mathrm{Si}-\mathrm{O}-\mathrm{Al}\right]$, $1029.9288 \mathrm{~cm}^{-1}$ stretching $[\mathrm{Si}(\mathrm{Al}) \mathrm{O}], 1645.17 \mathrm{~cm}^{-1}$ [O-O] bond of water molecules bending $(\mathrm{OH})$, and around $3423.41 \mathrm{~cm}^{-1}$ region stretching $(\mathrm{OH})$.

Results of industrial wastewater: Samples were shown in Table 3. Physiochemical properties of industrial wastewater samples were drown in (Figure 4), Indicates $\mathrm{pH}$ for tannery wastewater (3.56), and $\mathrm{pH}$ for paints wastewater (8.40). In comparison the Arab Industrial Development and Mining Organization (AIDMO) standards (May 2001) where $\mathrm{pH}$ range [6-9], tannery wastewater is acidic, and paints wastewater is acceptable.

In comparison the AIDMO standards where the concentrations of total dissolved solids (TDS) does not exceed (1200 ppm), tannery wastewater $(32100 \mathrm{ppm})$ has a very high value, where electricity wastewater (435 ppm) has acceptable value. This explains the high conductivity of tannery wastewater $(53.100 \mu \mathrm{s} / \mathrm{cm})$.

In comparison the AIDMO standards for biological oxygen demand BOD (30 ppm), tannery wastewater has a high value (53.34 $\mathrm{ppm})$, while and paints wastewater is acceptable (7.5 ppm). Chemical oxygen demand (COD) in tannery wastewater (3000 ppm), and petroleum wastewater (112 ppm) are high in comparison the AIDMO standards $(10 \mathrm{ppm})$. Total hardness in tannery wastewater is 1012.78 $\mathrm{ppm}$, but it is much lower in petroleum wastewater (34.56 ppm). High concentrations of heavy metal ions were shown in Table 4 . Thus it is concluded that tannery wastewater has many pollutants discharged directly without treatment to the river. Removals of heavy metals by scolecite were drowning in used SPSS IBM version 20 were shown in

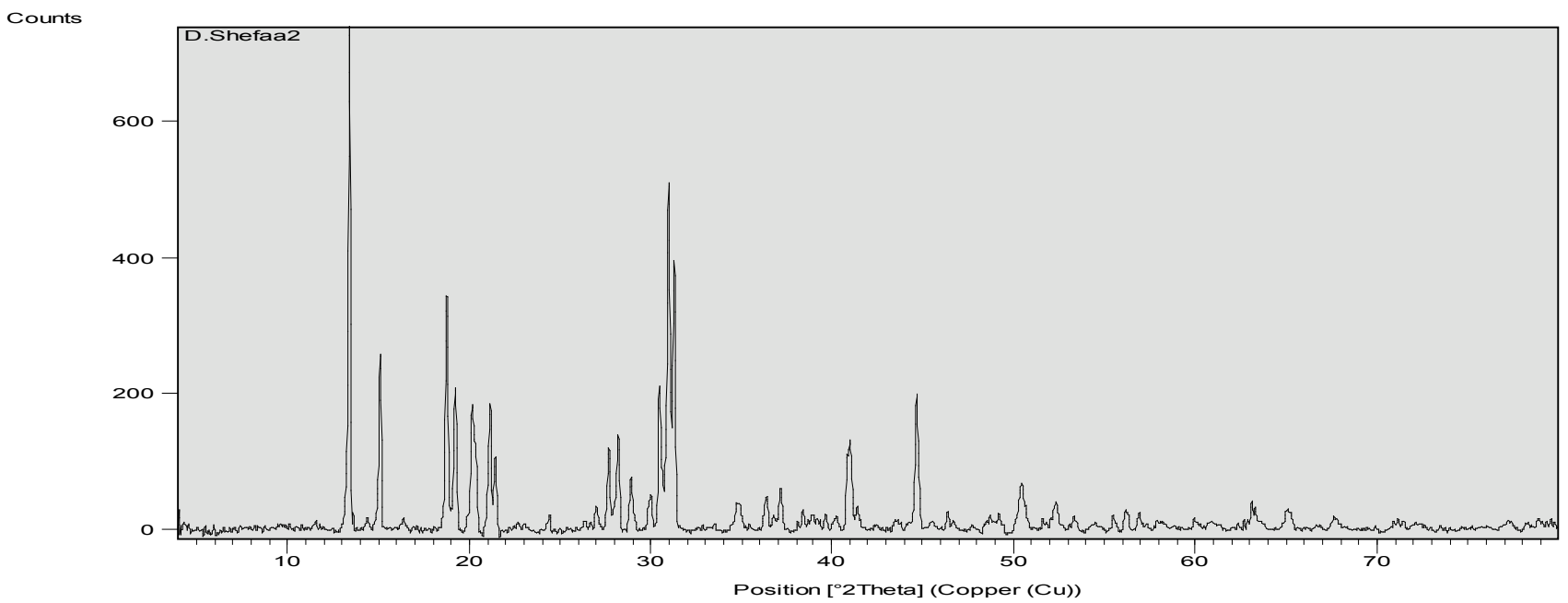

Figure 1: XRD Patterns for scolecite zeolite. 
Citation: Almalih MA, Salih A, Dafaallah AA, Magid SAA, Gizouli AME, et al. (2015) Removal of Heavy Metal lons from Industrial Wastewater by Scolecite. J Environ Anal Toxicol 5: 302. doi:10.4172/2161-0525.1000302

Page 3 of 5

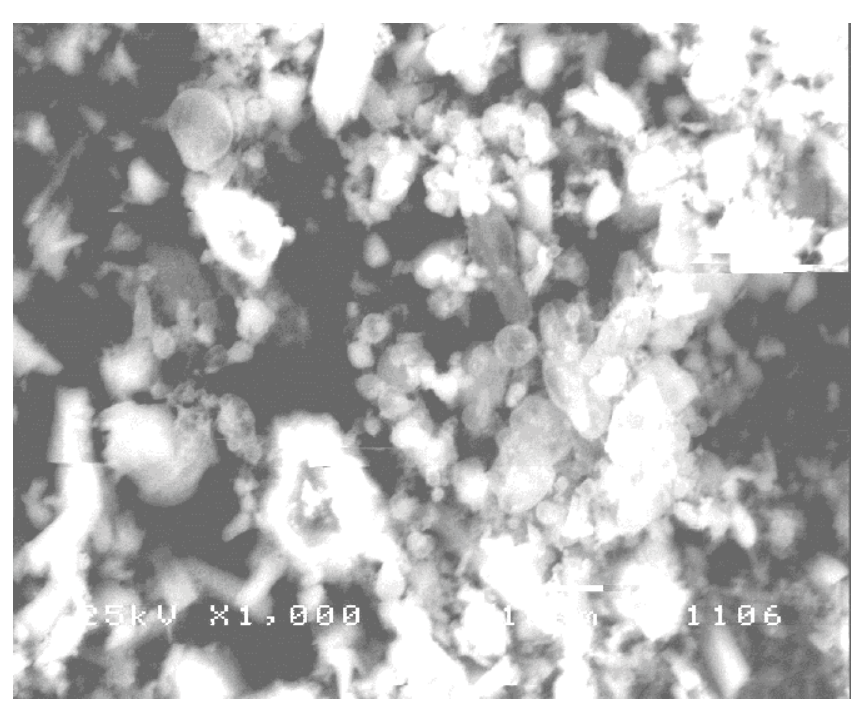

Figure 2: Show SEM image for scolecite.

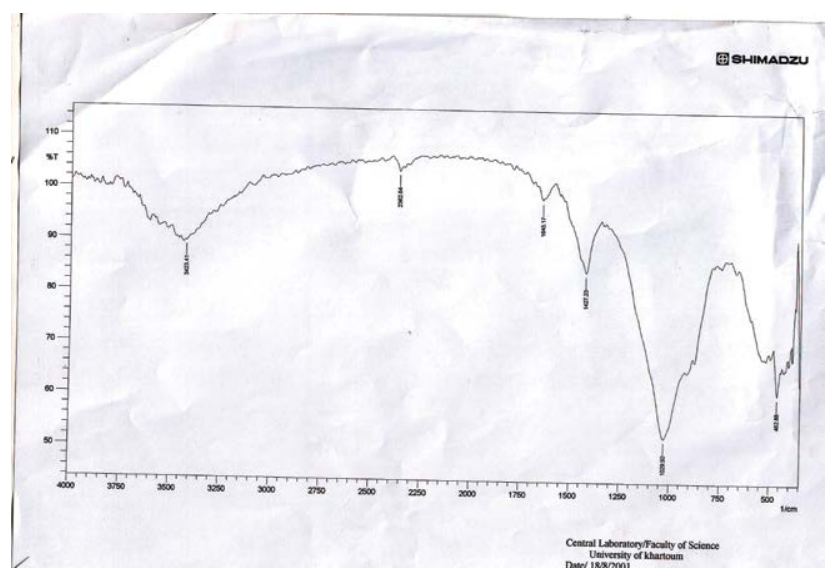

Figure 3: I.R for scolecite

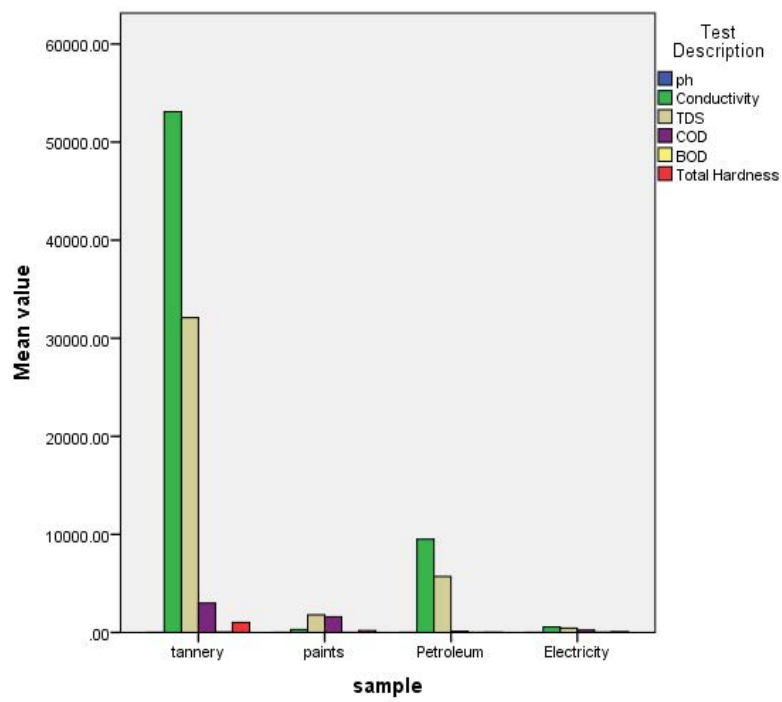

Figure 4: Show physiochemical properties results of industrial wastewater.

\begin{tabular}{|c|l|}
\hline Characteristic & Sources \\
\hline Physical properties & \\
\hline Color & $\begin{array}{l}\text { Domestic and industrial wastes, natural decay of organic } \\
\text { materials. }\end{array}$ \\
\hline Solids & $\begin{array}{l}\text { Domestic water supply, domestic and industrial wastes, } \\
\text { soil erosion, inflow, and infiltration. }\end{array}$ \\
\hline Chemical constituents \\
\hline Heavy metals & Industrial wastes. \\
\hline pH & Domestic, commercial, and industrial wastes. \\
\hline Nitrogen & Domestic and agriculture wastes. \\
\hline Sulfur & $\begin{array}{l}\text { Domestic water supply, domestic, commercial and } \\
\text { industrial wastes. }\end{array}$ \\
\hline Methane & Decomposition of domestic wastes. \\
\hline Archaebacteria & $\begin{array}{l}\text { Domestic wastes, surface water infiltration, treatment } \\
\text { plants. }\end{array}$ \\
\hline
\end{tabular}

Table 1: Physical, chemical, and biological characteristics of wastewater and their sources [10].

\begin{tabular}{|c|c|}
\hline Component (\%) & Scolecite (\%) \\
\hline $\mathrm{SiO}_{2}$ & 43.48 \\
\hline $\mathrm{AL}_{2} \mathrm{O}_{3}$ & 12.98 \\
\hline $\mathrm{Fe}_{2} \mathrm{O}_{3}$ & 10.07 \\
\hline $\mathrm{CaO}$ & 11.82 \\
\hline $\mathrm{MgO}$ & 6.08 \\
\hline $\mathrm{Na}_{2} \mathrm{O}$ & 2.59 \\
\hline $\mathrm{K}_{2} \mathrm{O}$ & 1.75 \\
\hline $\mathrm{SO}_{3}$ & 0.00 \\
\hline $\mathrm{Cl}$ & 0.114 \\
\hline $\mathrm{LOI}$ & 11.12 \\
\hline
\end{tabular}

Table 2: Chemical composition of scolecite by XRF.

\begin{tabular}{|c|c|c|c|c|}
\hline Waste & $\begin{array}{c}\text { Tannery } \\
\text { wastewater }\end{array}$ & $\begin{array}{c}\text { Paints } \\
\text { wastewater }\end{array}$ & $\begin{array}{c}\text { Petroleum } \\
\text { wastewater }\end{array}$ & $\begin{array}{c}\text { Electricity } \\
\text { wastewater }\end{array}$ \\
\hline pH & 3.56 & 8.40 & 7.58 & 8.04 \\
\hline Conductivity & $53100 \mu \mathrm{s} / \mathrm{cm}$ & $299 \mu \mathrm{s} / \mathrm{cm}$ & $9500 \mu \mathrm{s} / \mathrm{cm}$ & $544 \mu \mathrm{s} / \mathrm{cm}$ \\
\hline TDS & $32100 \mathrm{ppm}$ & $1807 \mathrm{ppm}$ & $5710 \mathrm{ppm}$ & $435 \mathrm{ppm}$ \\
\hline BOD & $53.34 \mathrm{ppm}$ & $7.5 \mathrm{ppm}$ & $9.65 \mathrm{ppm}$ & $27.7 \mathrm{ppm}$ \\
\hline COD & $3000 \mathrm{ppm}$ & $1600 \mathrm{ppm}$ & $112 \mathrm{ppm}$ & $250 \mathrm{ppm}$ \\
\hline Total hardness & $1012.78 \mathrm{ppm}$ & $184.79 \mathrm{ppm}$ & $34.56 \mathrm{ppm}$ & $74 \mathrm{ppm}$ \\
\hline
\end{tabular}

Table 3: Physiochemical properties for industrial wastewater.

\begin{tabular}{|c|c|c|c|c|}
\hline $\begin{array}{c}\text { Wastewater } \\
\text { Heavy metals }\end{array}$ & $\begin{array}{c}\text { Tannery } \\
\text { wastewater } \\
\text { ppm }\end{array}$ & $\begin{array}{c}\text { Paints } \\
\text { wastewater } \\
\text { ppm }\end{array}$ & $\begin{array}{c}\text { Petroleum } \\
\text { wastewater } \\
\text { ppm }\end{array}$ & $\begin{array}{c}\text { Electricity } \\
\text { wastewater } \\
\text { ppm }\end{array}$ \\
\hline $\mathrm{Ni}^{2+}$ & 20.0 & 4.0 & 2.25 & 0.923 \\
\hline $\mathrm{Pb}^{2+}$ & 1.26 & 3.67 & 3.89 & 4.882 \\
\hline $\mathrm{Zn}^{2+}$ & 1.23 & 0.095 & 0.003 & 0.00 \\
\hline $\mathrm{Cd}^{2+}$ & 7.40 & 0.001 & 0.00 & 0.00 \\
\hline $\mathrm{Fe}^{3+}$ & 1.83 & 0.014 & 0.00 & 0.020 \\
\hline $\mathrm{Cr}^{3+}$ & 6000.0 & 5.62 & 0.35 & 11.785 \\
\hline
\end{tabular}

Table 4: Concentrations of heavy metal ions in industrial wastewater by AAS 
Citation: Almalih MA, Salih A, Dafaallah AA, Magid SAA, Gizouli AME, et al. (2015) Removal of Heavy Metal lons from Industrial Wastewater by Scolecite. J Environ Anal Toxicol 5: 302. doi:10.4172/2161-0525.1000302

Page 4 of 5

Table 5. Scolecite removed $95.8,88.1,48,50,19.7$ and $99.9 \%$ of $\mathrm{Ni}^{2+}, \mathrm{Pb}^{2+}$, $\mathrm{Zn}^{2+}, \mathrm{Cd}^{2+}, \mathrm{Fe}^{3+}$ and $\mathrm{Cr}^{3+}$ metal concentrations respectively. According to the percentage removal values, the selectivity sequence of studied metals by scolecite can be given as $\mathrm{Cr}^{3+}>\mathrm{Ni}^{2+}<\mathrm{Pb}^{2+}<\mathrm{Cd}^{2+}<\mathrm{Zn}^{2+}>\mathrm{Fe}^{3+}$ (Figure 5). These results show that scolecite hold great potential to remove cationic heavy metal species from industrial wastewater.

\section{Conclusion}

In the present study, we characterized industrial wastewater
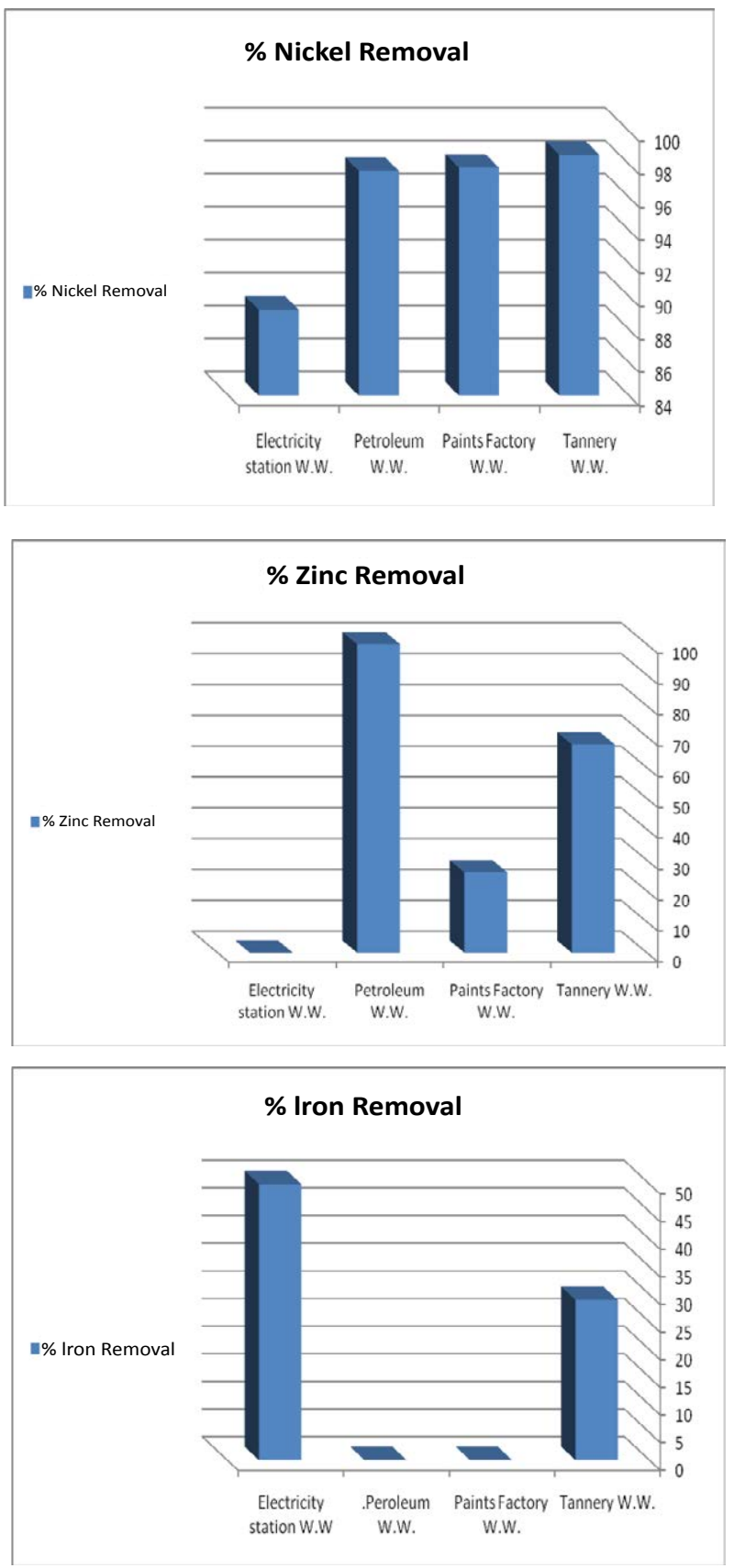

effluents, results indicated that many toxic pollutants drained directly to river and affected dangerously to environment. Scolecite natural zeolite is capable of removing metal ions $\mathrm{Ni}^{2+}, \mathrm{Pb}^{2+}, \mathrm{Zn}^{2+}, \mathrm{Cd}^{2+}, \mathrm{Fe}^{3+}$, $\mathrm{Cr}^{3+}$ from industrial waste water samples. The percentage of removal heavy metal ions by scolecite $95.8,88.1,48,50,19.7$ and $99.9 \%$ of $\mathrm{Ni}^{2+}, \mathrm{Pb}^{2+}, \mathrm{Zn}^{2+}, \mathrm{Cd}^{2+}, \mathrm{Fe}^{3+}$ and $\mathrm{Cr}^{3+}$. The obtained results showed that natural zeolite can be used effectively for the removal of these metal ions from industrial wastewater. This naturally occurring material provides a substitute for the use of other materials as adsorbent due to its availability and its low cost.
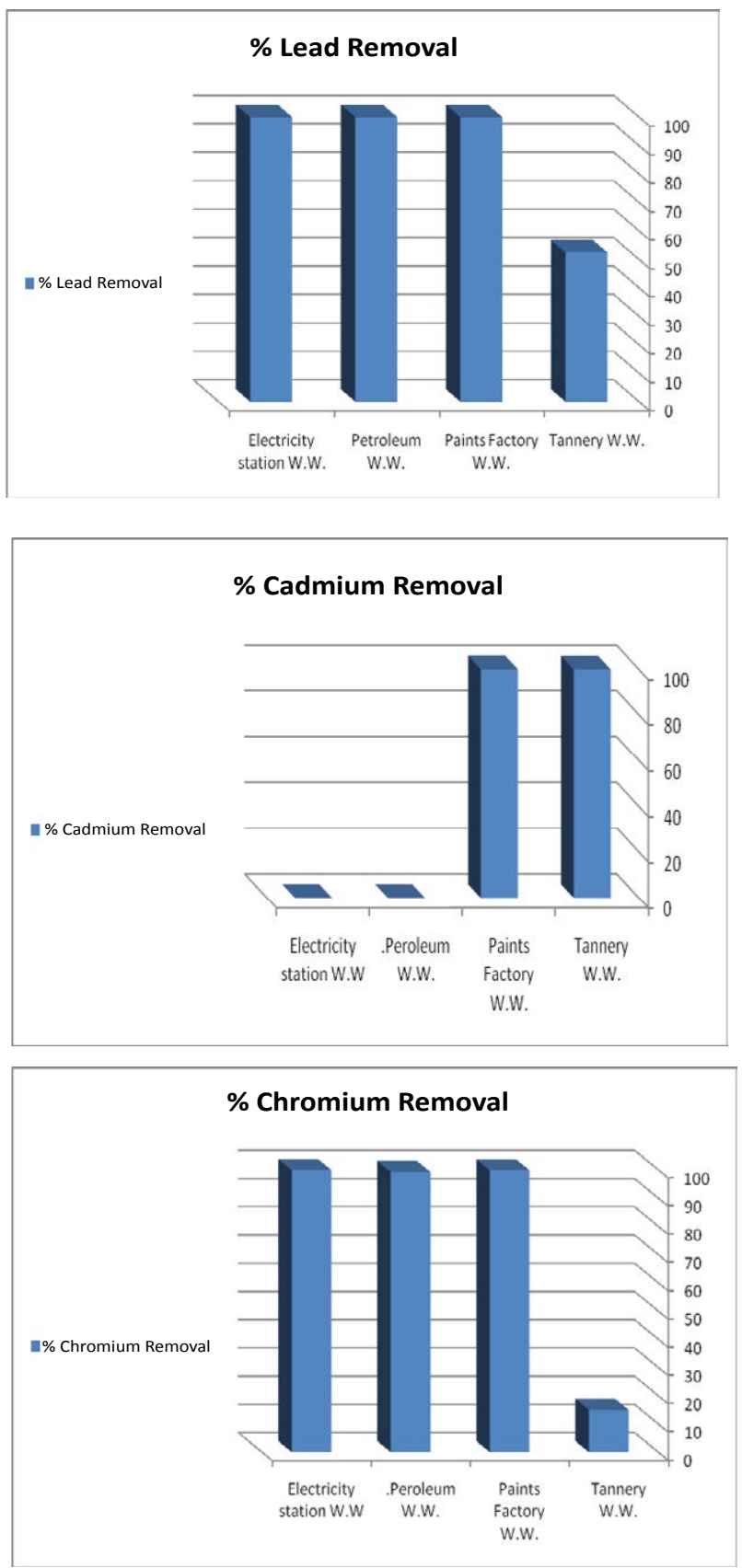
Citation: Almalih MA, Salih A, Dafaallah AA, Magid SAA, Gizouli AME, et al. (2015) Removal of Heavy Metal lons from Industrial Wastewater by Scolecite. J Environ Anal Toxicol 5: 302. doi:10.4172/2161-0525.1000302

\begin{tabular}{|c|c|c|c|c|}
\hline Heavy metal ions & sample & Mean & Std. Deviation & $\mathbf{N}$ \\
\hline \multirow[t]{5}{*}{$\mathrm{Ni}^{2+}$} & tannery & 98.6 & . & 1 \\
\hline & paints & 97.8 & . & 1 \\
\hline & Petroleum & 97.6 & . & 1 \\
\hline & Electricity & 89.2 & . & 1 \\
\hline & Total & 95.8 & 4.42116 & 4 \\
\hline \multirow[t]{5}{*}{$\mathrm{Pb}^{2+}$} & tannery & 52.4 & . & 1 \\
\hline & paints & 100 & . & 1 \\
\hline & Petroleum & 100 & . & 1 \\
\hline & Electricity & 100 & . & 1 \\
\hline & Total & 88.1 & 23.8 & 4 \\
\hline \multirow[t]{5}{*}{$\mathrm{Zn}^{2+}$} & tannery & 67.5 & . & 1 \\
\hline & paints & 26 & . & 1 \\
\hline & Petroleum & 100 & . & 1 \\
\hline & Electricity & 0 & . & 1 \\
\hline & Total & 48.375 & 44.24058 & 4 \\
\hline \multirow[t]{5}{*}{$\mathrm{Cd}^{2+}$} & tannery & 99.9 & . & 1 \\
\hline & paints & 100 & . & 1 \\
\hline & Petroleum & 0 & . & 1 \\
\hline & Electricity & 0 & . & 1 \\
\hline & Total & 49.975 & 57.70617 & 4 \\
\hline \multirow[t]{5}{*}{$\mathrm{Fe}^{3+}$} & tannery & 29 & . & 1 \\
\hline & paints & 0 & . & 1 \\
\hline & Petroleum & 0 & . & 1 \\
\hline & Electricity & 50 & . & 1 \\
\hline & Total & 19.75 & 24.36357 & 4 \\
\hline \multirow[t]{5}{*}{$\mathrm{Cr}^{3+}$} & tannery & 15 & . & 1 \\
\hline & paints & 99.8 & . & 1 \\
\hline & Petroleum & 99.2 & . & 1 \\
\hline & Electricity & 99.9 & . & 1 \\
\hline & Total & 78.475 & 42.3178 & 4 \\
\hline \multirow[t]{5}{*}{ Total } & tannery & 60.4 & 35.15969 & 6 \\
\hline & paints & 70.6 & 45.37559 & 6 \\
\hline & Petroleum & 66.1333 & 51.23416 & 6 \\
\hline & Electricity & 56.5167 & 47.4802 & 6 \\
\hline & Total & 63.4125 & 42.5116 & 24 \\
\hline
\end{tabular}

Table 5: Descriptive statistics of scolecite - Dependent variable: \% removal.

\section{References}

1. Dwight JD, Brian M, Eugene EF, Abraham R, Skinner H, et al. (1997) Dana's New Mineralogy. (8thedn), Wiley-Interscience, Hoboken, New Jersey, USA.

2. Pansini M (1996) Natural zeolites as cation exchangers for Environmental protection. Miner Deposita 31: 563-575.

3. Zamzow MJ, Eichbaum BR, Sandgreen KR, Shanks DE (1990) Removal of heavy metals and other cations from wastewater using zeolites. Sep Sci Technol 25: 1555-1569.
4. Ouki SK, Kavannagh M (1999) Treatment of metal-contaminated Wastewaters by use of natural zeolites. Water Sci Technol 39: 115-122.

5. Misaelides P, Godelitsas A, Noli F, Kossionidis S (1998) ${ }^{12}$ C-RBS investigation of scolecite crystals interacted with Cs-and $\mathrm{Sr}$-aqueous solutions. Nucl Instrum Methods Phys Res Sect B 139: 249-252.

6. Jacobs PH, Forstner U (1999) Concept of sub aqueous capping of contaminated sediments with active barrier systems (ABS) using natural and modified zeolites. Wat Res 33: 2083-2087.

7. Carvalho WA, Bosco SMD, Jimenez RS (2005) Removal of toxic metals from wastewater by Brazilian natural scolecite. J Colloid Interface Sci 281: 424-431.

8. Arceiala SJ, Asolekar SR (2007) Wastewater Treatment for Pollution Contro and Reuse (3rdedn), New Delhi: Tata Mc Graw-Hill Publishing Company Limited.

9. Metcalf, Eddy (1998) Wastewater Engineering Treatment. Disposal. Reuse (3rdedn), New Delhi: Tata Mc.Graw- Hill Publishing Company Itd. Pp. 48-68.

10. Kesraoui-Ouki S, Cheeseman CR, Perry R (1994) Natural Zeolite utilization in pollution control: A review to applications to metal effluents. J Chem Techno Biotechnol 59: 121-126.

11. Blanchard G, Maunaye M, Martin G (1984) Removal of heavy metals from water by means of natural zeolites. Water Res 18:1501-1507. 